\title{
Analysis on Competitiveness in Development of Ecological Tourism in North Scenic Area of Changbai Mountain
}

\author{
Mingju Liu \\ Yatai School of Business \\ Jilin University of Finance and Economics \\ Changchun, China 130117
}

\author{
Liguang Zhao \\ School of Taxation \\ Jilin University of Finance and Economics \\ Changchun, China 130117
}

\author{
Yan Zhang \\ Yatai School of Business \\ Jilin University of Finance and Economics \\ Changchun, China 130117
}

\begin{abstract}
Nowadays, ecological tourism has become popular in the development of tourist industry, referring to the tourist activity that has dual responsibilities of protecting natural environment and maintaining living of local people. According to the concept and characteristics of ecological tourism and the current situation of researches on ecological tourism at home and abroad, the competitive advantage of developing ecological tourism in north scenic area of Changbai Mountain is analyzed through analysis of current situation and problems in development of ecological tourism in north scenic area of Changbai Mountain. Strategies to develop ecological tourism are proposed.
\end{abstract}

Keywords-north scenic area of Changbai Mountain; ecological tourism; competitiveness

\section{INTRODUCTION TO ECOLOGICAL TOURISM}

\section{A. Concept of Ecological Tourism}

Ecological tourism was first proposed by Ceballos Lascurain in 1983. In 1990, the International Ecotourism Society defined it as a tourism behavior that protects environment and raises income of local residents in certain natural region.

Ecological tourism has two key points: the main body of it is natural scenes; the main body of it shouldn't be destroyed. Nowadays, people face environmental crisis and have consciousness of environmental protection. Green tourism and green consumption are popular at present. As activity of green tourism, ecological tourism causes a big stir worldwide when it appears. The concept of ecological tourism is rapidly popularized and its meanings expand continuously. At present, the living environment of people degrades unceasingly. On the

Fund program: National Natural Science Foundation of China (project number: 41401146); Science and Technology Development Project in Jilin Province (20150204NY); Project of Education Department in Jilin Province (JJKH20170140SK). basis of the first key point, the ecological tourism is defined as "Tourism Returning to Nature" and "Green Tourism"; according to environmental problems in the development of tourist industry, on the basis of the second key point, the ecological tourism is defined as "Conservation Tourism" and "Tourism with Sustainable Development". At the meantime, countries in the world form ecological tourism with unique features according to national conditions.

Ecological tourism takes distinctive ecological environment as the main landscape, sustainable development as the concept, the protection of ecological environment as the premise and the harmonious development of human and nature as the criterion. Depending on benign natural ecological environment and unique humanistic ecological system, it carries out ecological experience, ecological education and ecological cognition to make people get physical and mental pleasure through ecological and friendly ways.

\section{B. Characteristics of Ecological Tourism}

1) Sustainability: Ecological tourism refers to the tourist activity depending on ecological system in the natural environment, in order to narrow the gap between influences on the environment caused by our subjective wishes and practical actions. It first considers the bearing capacity of ecological environment, values the researches on carrying capacity of tourist environment and measures to protect tourist environment and emphasizes the dedication of tourists and employees to ecological protection. These norms and measures will inevitably strengthen the sustainable development of tourism resources.

2) Naturalness: Tourist destinations have unique natural ecological landscape and sparse population as well as stay away from the downtown. It preserves the original ecological environment because of the low degree of influence of 
industrialization. It has unique history and realistic culture and original life style and cultural patterns which attract tourists. Tourists travel to some places to understand, observe and experience cultures different from their own. Special tourist projects and routes designed for tourist destinations should meet the requirements of centralized ecological environmental characteristics and harmonious coexistence of natural geological condition and humanistic condition, letting tourists have unprecedented experience. Ecological tourism depends on ecological environment and natural resources and integrates natural environment with tourist. Natural environment is always the carrier of tourists.

3) Protectiveness: Compared with the traditional tourist activities in China, modern ecological tourism has the biggest characteristic of protectiveness. In the past, tourism was the activity participated by a few people and did not influence the tourist environment, so the protection of ecological resources wasn't proposed. After the industrial revolution, people's living standard improves and tourism becomes popular. The development and management of tourism don't have mature system and emergency plan. Promoted by sustainable development, people realize if we do not protect the environment timely, tourism will destroy the last natural and cultural heritages of human surviving from the industrial revolution.

The protectiveness of ecological tourism embodies in many aspects of tourist industry. Planners should develop and design tourism products through following natural ecological law and harmony and unity of human and nature. Tourism developers should seek benefits through realizing the economic value of tourism resources and scientific development. Tourism administrators should utilize tourism within the carrying capacity of natural environment and seek sustainable and coordinated development. Tourist should improve selfaccomplishment and protect ecological tourism resources and environment consciously.

4) Universality: At the initial stage of ecological tourism, specific crowd participate in the ecological tourism such as those with higher education and cultural quality. Most of them are attracted by the charm of nature. They have high living standard, stable job and considerable income, a wide range of knowledge and high taste. But in recent years, the tourists participating in ecological tourism are not confined to specific crowd. An increasingly number of students and common workers participate in it. With social and economic development, ecological tourism will become people's basic demand in life.

5) Participation: Ecological tourism enables tourists to participate in the ecological system to experience the mystery of it and love nature, making for the protection of natural and cultural tourism resources. Tourists can get distinctive and new tourism experience. Tourists, local residents, tourism operators and administrators participate in ecological tourism.

\section{ANALYSIS ON CURRENT SITUATION OF ECOLOGICAL TOURISM AT HOME AND ABROAD}

\section{A. Current Situation of Ecological Tourism Abroad}

As the representative of green tourism, ecological tourism is regarded as the inevitable choice to realize sustainable development of the tourist industry. Ecological tourism has become the most influential industry with the most rapid development in the world at present, referring the leading main body in tourist industry and beautiful scenery. The United Nations have set the year of 2002 as the international ecological tourism year and stimulate countries to carry out ecological tourism, in order to let people value the ecological tourism and the environment.

Developed countries first carry out the ecological tourism. With solid national strength, they greatly support the ecological tourism. The government manages strictly and better considers ecological and social benefits except for economic benefits to make the protection more effective. They also pay attention to the development of ecological tourism. Most countries have established organizations related to ecological tourism to protect the environment and let people value the ecological tourism. Ecological tourism cannot develop without the strong support of government. Laws related to ecological tourism have been made in foreign countries for people to abide by. It takes benefits of local residents into full consideration. Internationally, the ecological tourism has had mature development. Ecological tourism brings benefits for local residents and optimizes their living environment. People in foreign countries develop ecological tourism at the same time protect the ecological system.

\section{B. Current Situation of Ecological Tourism at Home}

Ecological tourism is the primary inevitable choice of tourist industry and has got attentions and rapid development in the world. The ecological tourism in our country is at the initial stage. But the development of ecological tourism in China has many advantages including the high market demands. As the hot spot of development in tourist industry, ecological tourism increases most rapidly in all tourism products. Tourism makes people get the experience that they cannot get in daily life. People can enjoy the sight of natural landscape and scenic spots and historic sites in travel to relieve the pressure in life and busy work. With the scientific progress and economic development, the increase of work stress and fast rhythm of life, people have increasingly strong demands for nature. Returning to nature has become an enjoyment. The ecological tourism in our country has huge potential market. With the improvement of people's living standard, more attentions are paid to ecological tourism. It is the impetus for the development of ecological tourism in our country.

The ecological tourism in our country has a short development history and many systems are imperfect. Most tourists think I have to get payback since I spend the money, so some uncivilized behaviors appear, such as they carve characters of "I have traveled thus far" on scenic spots and historic sites, spit on the ground and litter in scenic spots. True ecological tourists pursue the feeling of beauty. Chinese people have a shallow understanding of the concept of ecological 
tourism, so they have behaviors that cause damage to the environment. Although the development of ecological tourism in our country is at the initial stage, we can refer to much successful experience. The ecological tourism will realize through integration of successful experience in ecological tourism of some foreign country with the physical truth of ecological tourism in our country.

\section{ANALYSIS ON THE DEVELOPMENT STATUS OF ECOlOGICAL TOURISM IN NORTH SCENIC AREA OF CHANGBAI MOUNTAIN}

\section{A. Introduction to north Scenic Area of Changbai Mountain}

The north scenic area of Changbai Mountain locates in the foot of the north slope of Changbai Mountain. The administrative division is in Chibei District of Changbai Mountain. It is the tourism landscape with the earliest development in our country. With complete functions and sound facilities, it receives more than one million tourists annually. We can enjoy the four famous landscapes including vertical landscape belt, hot spring group, Changbai Waterfall and Tianchi. The original landscapes including Beauty Pine, Underground Forest, Small Tianchi, Green Deep Pool, Grand Canyon, Erdaobaihe River and Yue Birch Forest make people enjoy themselves so much as to forget to leave.

Located in the north scenic area of Changbai Mountain, Tianchi is the deepest, largest and highest alpine lake. Most mysteriously, Tianchi only has water outlet instead of water inlet. The lake water flows out continuously all the year round. Since ancient times, the legend of monster in Tianchi has existed, adding charming color to Tianchi. Changbai Mountain has abundant water resources and the good reputation of "the Source of Water". Located in north side of Tianchi, with the height of 68 meters, Changbai Waterfall is formed by water that flows along the Chengcha River to the place of 1,250 meters. As the most representative scenery, Changbai Waterfall has the biggest characteristic that water flows unceasingly throughout the year. The hot spring can reach the highest temperature of $83^{\circ} \mathrm{C}$, which is very high. The eggs boiled in the hot spring are called the "golden egg of Changbai Mountain". Small Tianchi is a parasitic crater lake with water inlet instead of water outlet. The water level remains unchanged throughout the year no matter in drought or rainy days. Underground Forest is the scenic spot in Changbai Mountain with the lowest altitude. The place in eighteen to nineteen kilometers of the highway in the district is the entrance to visit Underground Forest which forms when volcano erupts accompanied by earthquake to make the earth's surface sink. The north scenic area of Changbai Mountain has other spectacular landscapes.

\section{B. Development Status of Ecological Tourism in North Scenic Area of Changbai Mountain}

The management system of ecological tourism in north scenic area of Changbai Mountain is imperfect. The ecological environment degrades increasingly. The highway in conservation area destroys the tundra where water and soil loss exists. Under the stimulation of interests, the tourist number isn't controlled in peak tourist season. The absence of pollution protection and detection causes the degradation and pollution of environment. The adequate development and the concentration of tourists around Tianchi make the excessive environment capacity and cause damage to vegetation. The reason why these problems exist in development of ecological tourism in north scenic area of Changbai Mountain is that people neither protect environment nor develop other tourism resources evenly in the development ecological tourism. People carry out ecological tourism blindly to seek interests before understanding it, so it causes immature development of ecological tourism and environmental pollution and destruction.

\section{ANALYSIS ON STRENGTHS AND WEAKNESSES IN} DEVELOPMENT OF ECOLOGICAL TOURISM IN SCENIC AREA OF ChangBai Mountain

\section{A. Analysis on Strengths of Implementing Ecological Tourism}

1) Rich tourism resources: Abundant tourism resources in north scenic area of Changbai Mountain contributes to the development of ecological tourism. Changbai Mountain has superior geographic position. The diversification of natural landscapes creates various tourism resources for tourists. The diversified ecological environment lays a solid foundation for the development of ecological tourism.

2) Great market demands: As the hot topic nowadays, ecological tourism can bring considerable economic benefits, referring to the development direction of tourism industry. Ecological tourism has the strength of great market demands. With increasingly high living standard, people have more and more requirements for tourism, so the development of ecological tourism is promising.

3) Use tourism resources reasonably: The implementation of ecological tourism can use ecological resources properly and turn the tourist industry into green tourism that has minimum influence on the environment and maintains the ecological system with sustainable development. It makes tourists satisfied to protect and devote to nature, better protect ecological environment and our living space.

\section{B. Analysis on Weaknesses of Implementing Ecological Tourism}

1) Few products of ecological tourism: The product type of ecological tourism in north scenic area of Changbai Mountain is too simple. Most tourists choose on-day tour to visit Tianchi and Underground Forest which are tourism products for sightseeing. In the era with developed science and technology, it lacks projects of scientific and technological education and products with ecological tourism as the theme. The low level products, absence of high level participation and the insufficient exertion of functions of forest tourism resources in north scenic area of Changbai Mountain lead to tourists' short duration of stay, low secondary tourism rate and decrease of tourists.

2) Low investment: Diversification of investment will greatly promote the development of ecological tourism. The investment and funding channels of tourism in forest region of Erdaobaihe and the private investment are limited. The 
introduction of foreign capital starts late. At present, the capitals are from government support but the government fails to clearly understand the investment in developing forest ecological tourism.

3) Poor knowledge of ecological tourism: Administrative staff in tourism of Erdaobaihe are insufficient. The development and operation of forest ecological tourism is blind so the forest ecological system in real sense doesn't form. Staff in forestry of north scenic area of Changbai Mountain don't have consciousness of forest ecological system. They fails to participate in it and sometimes even damage resources of forest ecological tourism.

\section{COUNTERMEASURES TO DEVELOP ECOLOGICAL} TOURISM IN NORTH SCENIC AREA OF CHANGBAI MOUNTAIN

\section{A. Reasonable Planning}

The premise of ecological tourism in north scenic area of Changbai Mountain is planning. The development of tourism in north scenic area should have management system to solve problems in belonging, operation and benefits of development in tourism resources of Changbai Mountain, develop orderly, reasonably plan and develop tourism resources in north scenic area of Changbai Mountain, and firmly implement the sustainable development of ecological tourism. The thought of environmental protection can prevent the damage to ecological resources and environment. In planning of north scenic area, it is necessary to survey biological resources, geological resources and resources related to environment quality, in order to take measures and reduce even eliminate source of pollution. In the development, behaviors that cause damage to natural environment shouldn't exist to guarantee high quality ecological tourism environment.

\section{B. Strengthen the Protection of Ecological Resources}

Complete ecological tourism system is the basis to attract tourists at home and abroad. The north scenic area of Changbai Mountain should implement the policy of returning the grain plots to forestry, accelerate ecological construction and seek development capital and increase the forest covered area. In the development of ecological tourism, avoid building largely and keep balance of ecological system. Reduce the number of wood processing and properly control the construction of newly-built wood processing enterprises, carry out measures and technology of new fuel and reduce wood consumption. Protect wildlife resources and create more opportunities for tourists to closely contact wild animals.

\section{Accelerate the Construction of Facilities in Ecological Tourism}

Tourist facilities of ecological tourism directly provide service. We must consider the bearing capacity of ecological environment and accelerate the construction of facilities in ecological tourism in north scenic area including accommodation service facilities like holiday village, hotel, tent and villa, traffic service facilities like walking tool and tour bus, as well as social service facilities like specialty restaurant, entertainment venues, travel agency, shopping store and medical service. The north scenic area of Changbai Mountain must increase the investment in construction of tourism infrastructure such as pollution discharge system, traffic and transportation system and greening facilities. The economic construction in north scenic area of Changbai Mountain must pay attention to the project development in tourist attractions like ski resort, form one package service system of food, accommodation, travel, shopping and entertainment, in order to make the north scenic area of Changbai Mountain into the ecological tourism resort of Changbai Mountain even Jilin Province.

\section{Strengthen the Development of Ecological Tourism Products}

Tourism products are diversified. The ecological tourism products in north scenic area of Changbai Mountain are comprehensive including material products and tourism services provided to the ecological tourism market to meet tourists' demands. It requires us to continuously improve the quality of tourism service, tourism resources, tourism facilities and tourism products to meet the requirements of tourists at home and abroad. Tourists return to nature, visit ecological landscape in north scenic area of Changbai Mountain and local customs and practices as well as cultures with regional difference. Therefore, we should strengthen the planning and development of tourism products local special products of natural green food, souvenirs and handicraft articles in north scenic area of Changbai Mountain.

\section{E. Intensify Publicity}

Renowned big brands depend on publicity. The publicity of ecological tourism in north scenic area is intensified to improve its popularity and good reputation in order to attract more tourists. Intensify the publicity that ecological tourism in north scenic area of Changbai Mountain benefits people's physical and psychological health and makes for environmental protection and let tourists get accustomed to the travel mode. The brand effect that Changbai Mountain is rated as one of the ten national famous mountains should be utilized to publicize the tourism resources, projects and environment in north scenic area of it. The atmosphere of developing ecological tourism can be created through ecological activities. Furthermore, they can intensify the social propaganda of ecological tourism in north scenic area of Changbai Mountain, carry out law awareness publicity and bring courses of ecological tourism in teaching, in order to improve people's awareness of ecological tourism and establish ecological tourism industry with sustainable development. Some pamphlets related to notice of ecological tourism can be provided to publicize the importance and popularize the knowledge of ecological tourism. People can realize the importance of ecological tourism and environment through publicity of ecological tourism through multiple channels.

\section{F. Strengthen Management According to Law}

The development of tourist industry cannot do without sound management of tourism through improving construction of organization structure in tourism management and providing enough and training tourism management personnel. We 
should make the best of coordination and motivation of tourism competent department for tourist industry. At the same time, strengthen control and supervise tourism market, correct errors and strengthen law enforcement efforts to strengthen people's consciousness of environmental protection. Implement and learn laws and regulations related to tourist industry, ecological tourism and environmental protection, strengthen legal sense and timely punish and deal with behaviors that cause damage to natural resources.

\section{CONCLUSION}

The north scenic area of Changbai Mountain is the tourism landscape area with the earliest development. It has sound infrastructure and functions and annual tourist amount of exceeding one million. Ecological tourism avails sustainable development of ecological environment in Changbai Mountain and drives the growth of local economy and improvement of people's living standard, referring to the development tendency of tourist industry in Changbai Mountain. With rich tourism resources and diversified species, Changbai Mountain has ecological surplus. Therefore, the development of ecological tourism is the inexorable trend of the development in north scenic area of Changbai Mountain.

\section{REFERENCES}

[1] Cao Minlu, etc. Guide to Ecological Tourism in China [M], Beijing: the Economic Daily Press, 1999

[2] Liu Mingju, etc. Thinking on Researches of Tourism Resources [J], Taxation and Economy, 2006(1)

[3] Cheng Yaning. Research on Development Strategy of Tourist Industry in Changbai Mountain Nature Reserve [D], Northeast Normal Univeristy, 2007

[4] Cheng Yanling, Liang Zhaocheng. Changbai Mountain Nature Reserve and Development of Ecological Tourism [J], Journal of Yanbian University, 2007

[5] Cao Guangcheng. Countermeasures for Development of Ecological Tourism in Changbai Mountain [J], Journal of Northeast Normal University, 2008

[6] Liu Mingju, etc. Research on Sustainable Development of Tourism in North Scenic Area of Changbai Mountain [J], Taxation and Economy, 2015(5)

[7] Cheng Huosheng. Research on Environmental Carrying Capacity and Sustainable Development of Ecological Tourism in Changbai Mountain [J], Journal of Agricultural Science Yanbian University, 2010. 